\title{
U-PB DETRITAL ZIRCON GEOCHRONOLOGY OF CRETACEOUS-CENOZOIC SEDIMENTARY ROCKS IN THE LADUE RIVER-MOUNT FAIRPLAY AREA, ALASKA
}

Evan Twelker and Paul O'Sullivan

Preliminary Interpretive Report 2021-2

This publication is PRELIMINARY in nature and meant to allow rapid release of field observations or initial interpretations of geology or analytical data. It has undergone limited peer review but does not necessarily conform to DGGS editorial standards. Interpretations or conclusions contained in this publication are subject to change.

2021

STATE OF ALASKA

DEPARTMENT OF NATURAL RESOURCES

DIVISION OF GEOLOGICAL \& GEOPHYSICAL SURVEYS
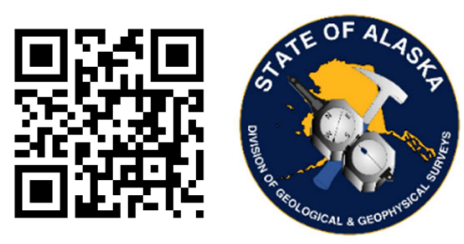
STATE OF ALASKA

Mike Dunleavy, Governor

\section{DEPARTMENT OF NATURAL RESOURCES}

Corri A. Feige, Commissioner

\section{DIVISION OF GEOLOGICAL \& GEOPHYSICAL SURVEYS}

Steve Masterman, State Geologist \& Director

Publications produced by the Division of Geological \& Geophysical Surveys are available to download from the DGGS website (dggs.alaska.gov). Publications on hard-copy or digital media can be examined or purchased in the Fairbanks office:

\section{Alaska Division of Geological \& Geophysical Surveys (DGGS)}

3354 College Road | Fairbanks, Alaska 99709-3707

Phone: 907.451.5010 | Fax 907.451.5050

dggspubs@alaska.gov $\mid$ dggs.alaska.gov

\section{DGGS publications are also available at:}

Alaska State Library, Historical

Collections \& Talking Book Center

395 Whittier Street

Juneau, Alaska 99801

Alaska Resource Library and

Information Services (ARLIS)

3150 C Street, Suite 100

Anchorage, Alaska 99503

\section{Suggested citation:}

Twelker, Evan, and O'Sullivan, P.B., 2021, U-Pb detrital zircon geochronology of CretaceousCenozoic sedimentary rocks in the Ladue River-Mount Fairplay area, Alaska: Alaska Division of Geological \& Geophysical Surveys Preliminary Interpretive Report 2021-2, 16 p. https://doi.org/10.14509/30683
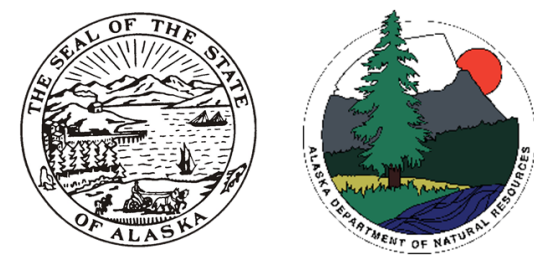


\section{U-PB DETRITAL ZIRCON GEOCHRONOLOGY OF CRETACEOUS-CENOZOIC SEDIMENTAY ROCKS IN THE LADUE RIVER MOUNT FAIRPLAY AREA, ALASKA Evan Twelker ${ }^{1}$ and Paul O'Sullivan ${ }^{2}$}

\section{INTRODUCTION}

This report presents $\mathrm{U}-\mathrm{Pb}$ detrital zircon dates from three sedimentary rock samples collected in the eastern Tanacross Quadrangle during 2019 geologic mapping by the Alaska Division of Geological \& Geophysical Surveys (DGGS; fig. 1). This geologic map is published concurrently by Twelker and others (2021). The data were collected to support the map interpretation by establishing maximum depositional ages (MDAs) for the sampled strata. Further, these results also bolster a regional detrital zircon dataset that will, collectively, further constrain the Cretaceous-Cenozoic paleogeography of the region. This work is of economic and scientific interest: placer gold in the Fortymile District originated in Jurassic orogenic veins (for example, Allan and others, 2013) and, in some areas, was transported and concentrated by CretaceousCenozoic depositional systems prior to its deposition in modern placer deposits. This process is described for the Coal Creek and Woodchopper Creek placers between Circle and Eagle (Cobb, 1973) and may be relevant elsewhere in the eastern Yukon Tanana Uplands.

The analytical data tables associated with this report are available in digital format as comma-separated value (CSV) files. Additional details about the organization of information are noted in the accompanying metadata file. All files can be downloaded from the DGGS website: https://doi.org/10.14509/30683.

\section{GEOLOGIC BACKGROUND}

Scattered exposures of non-marine sedimentary rocks occur throughout the eastern Yukon-Tanana uplands, and fossil pollen from these units indicate depositional ages that range from mid-Cretaceous to Neogene (Foster and Igarashi, 1990). Most of these rocks lie unconformably on metamorphic basement, or on top of mid-Cretaceous volcanic rocks (ca. 100-110 Ma), with or without an unconformity. In some locations, these sedimentary rocks are overlain by ca. $70 \mathrm{Ma}$ volcanic rocks. For example, the Indian River Formation is overlain by the Carmacks Group volcanic rocks in Yukon (Lowey and Hills, 1988; Gordey and Ryan, 2005), and conglomerate (unit Kc) is overlain by latest Cretaceous andesite (unit Kv) in the northeastern Tanacross Quadrangle (Wypych and others, 2021). In other instances, sedimentary rocks are cut by ca. $57 \mathrm{Ma}$ diabase dikes (Werdon and others, 2001) or are overlain by ca. 57 Ma rhyolite (Twelker and others, 2021). Other exposures are unconstrained by known geologic relationships. At some localities, both Cretaceous and Cenozoic sedimentary rocks are present and not macroscopically differentiable, such as north of Mount Fairplay and in the Chicken area, where plant fossils indicate ages as young as Neogene (Foster and Igarashi, 1990) and radiometric ages indicate both pre-57 Ma and mid-Cretaceous depositional ages (Werdon and others, 2001). Elsewhere, Paleogene conglomerate may lie directly on metamorphic and plutonic basement without any Cretaceous rocks present (for example, unit PEs of Twelker and others, 2021).

\footnotetext{
${ }^{1}$ Alaska Division of Geological \& Geophysical Surveys, 3354 College Road, Fairbanks, AK 99709-3707

${ }^{2}$ GeoSep Services, 1521 Pine Cone Road, Moscow, Idaho 83843-9316
} 


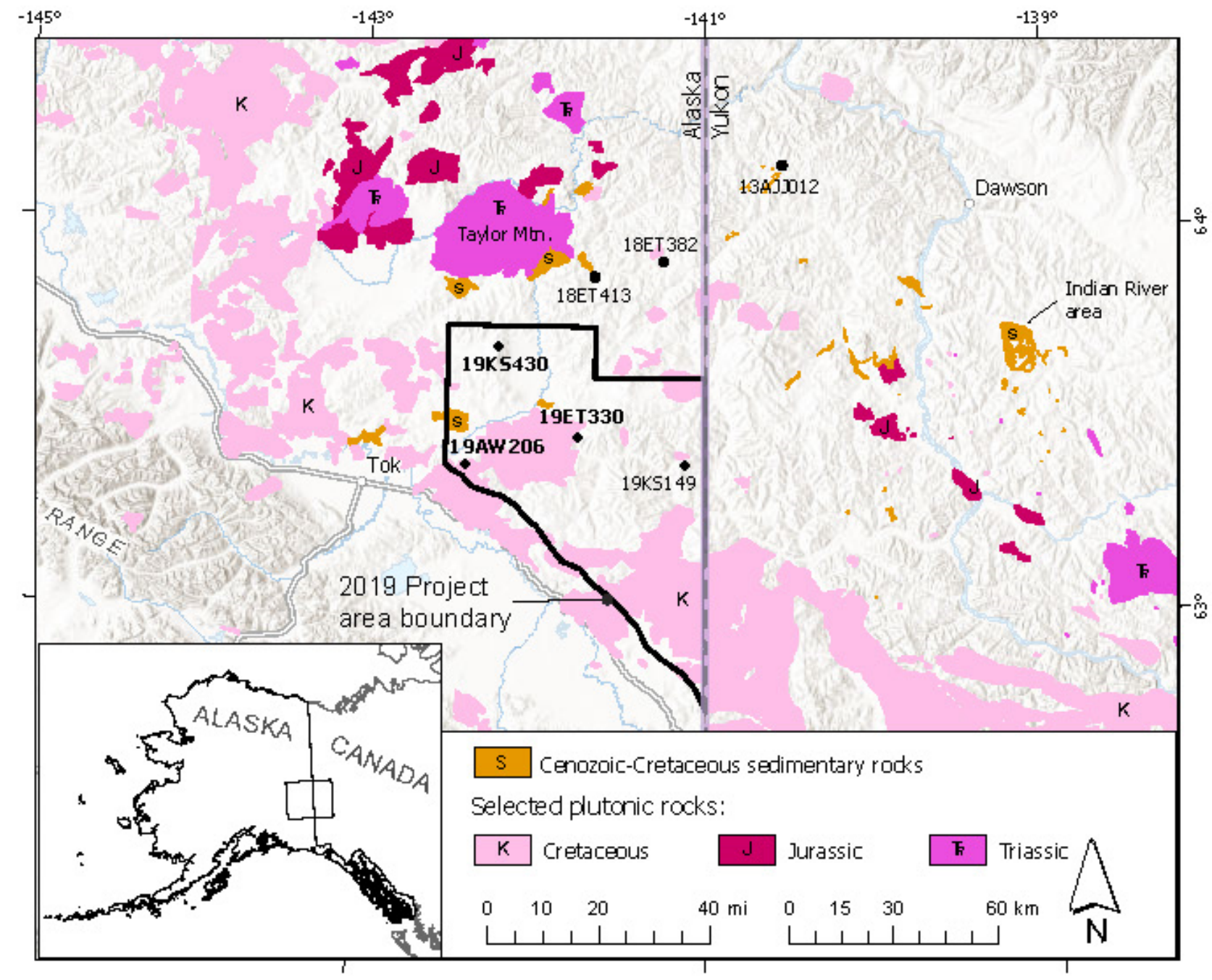

Figure 1. Map showing the 2019 DGGS project area and the location of the samples presented in this report (bold), the samples referenced in the discussion, and the mapped extent of Cretaceous-Cenozoic sedimentary rocks and Cretaceous, Jurassic, and Triassic plutonic rocks in this part of eastern Alaska (Wilson and others, 2015) and western Yukon (Yukon Geological Survey, 2019).

Foster and others (1994) suggest that the Cretaceous-Cenozoic strata in eastern Alaska were likely deposited in relatively small, disconnected sedimentary basins, at least some of which are associated with faults or volcanic rocks. To the east, Lowey and Hills (1988) interpreted mid-Cretaceous sedimentary rocks (Tantalus Formation; presently included in the Indian River formation of Yukon Geological Survey [2019]) of the Indian River area of the Yukon as the record of southwest-prograding fan-deltas with sediment sourced from the northeast.

\section{METHODS}

All sample processing and analytical work was undertaken by GeoSep Services (GSS), Idaho, USA. Zircon grains were isolated and prepared for laser-ablation, inductively coupled plasma mass spectrometer (LA-ICP-MS) analysis using standard procedures combined with specific customized procedures described by Donelick and others (2005). 


\section{U-Pb LA-ICP-MS methods}

Methods described here are similar to protocols employed by Bradley and others (2009), Hults and others (2013), and Moore and others (2015). Zircons (both standards and unknowns) were mounted in epoxy wafers and ground and polished to expose internal grain surfaces. Grains, and the locations for laser spots, were selected for analysis using transmitted light with an optical microscope at 2,000x magnification, which allows the recognition and characterization of features below the surface of individual grains.

Isotopic analyses were performed with a New Wave UP-213 laser ablation system in conjunction with an Agilent 7700x quadrupole LA-ICP-MS in the GeoAnalytical Lab at Washington State University. For all laser analyses, the beam diameter was $30 \mu \mathrm{m}$ and the frequency was set at $5 \mathrm{~Hz}$, yielding ablation pits $\sim 12-15$ $\mu \mathrm{m}$ deep. Helium and Ar gases were used to deliver the ablated material into the plasma source. Each analysis of 32 cycles took approximately 30 seconds to complete and consisted of a 6-second integration on peaks with the laser shutter closed (for background measurements) followed by a 24-second integration with the shutter open. A 20-second delay occurred between analyses. The isotopes measured included ${ }^{202} \mathrm{Hg},{ }^{204}(\mathrm{Hg}+\mathrm{Pb})$, ${ }^{206} \mathrm{~Pb},{ }^{207} \mathrm{~Pb},{ }^{208} \mathrm{~Pb},{ }^{232} \mathrm{Th},{ }^{235} \mathrm{U}$, and ${ }^{238} \mathrm{U}$.

Previous LA-ICP-MS studies of U-Pb zircon dating used the 'intercept' method, which assumes that isotopic ratio varies linearly with scan number due solely to linearly varying isotopic fractionation (Chang and others, 2006; Gehrels and others, 2008). The data modeling approach favored here was the modeling of background-corrected signal intensities for each isotope at each scan. Background intensity for each isotope was calculated using a fitted line (for decreasing background intensity) or using the arithmetic mean (for nondecreasing background intensity) at the global minimum of selected isotopes $\left({ }^{206} \mathrm{~Pb},{ }^{232} \mathrm{Th}\right.$, and $\left.{ }^{238} \mathrm{U}\right)$ for the spot. Background-plus-signal intensity for each isotope at each scan was calculated using the median of fitted (2nd-order polynomial) intensity values for a moving window (7 scans wide here) that includes the scan. The precision of each background-corrected signal intensity value was calculated from the precision of background intensity value and the precision of the background-plus-signal intensity value.

Several zircon $\mathrm{U}-\mathrm{Pb}$ age standards were used during analysis for calibration purposes. These included the $1099 \pm 0.6 \mathrm{Ma}$ FC zircon (FC-1 of Paces and Miller, 1993) as the primary age standard. The secondary age standard was the 61.2 \pm 0.1 Ma Tardree Rhyolite (TR) zircon (Dave Chew, personal communication). Thirdlevel age standards included the Fish Canyon Tuff with an age of 28.20 $\pm 0.1 \mathrm{Ma}$ (Lanphere and Baadsgaard, 2001), the Mount Dromedary Syenite with an age of $99.1 \pm 0.1 \mathrm{Ma}$ (Renne and others, 1998), and the Temora2 diorite with an age of $416.8 \pm 0.3 \mathrm{Ma}$ (Black and others, 2004). At the beginning of the LA-ICP-MS session, zircon standards (TR and FC-1) were analyzed until fractionation was stable and the variance in the measured ${ }^{206} \mathrm{~Pb} /{ }^{238} \mathrm{U}$ and ${ }^{207} \mathrm{~Pb} /{ }^{206} \mathrm{~Pb}$ ratios was at or near 1 percent. To correct for inter-element fractionation during the session, these standards were generally reanalyzed after each 15-25 unknowns.

Uranium decay constants and the ${ }^{238} \mathrm{U} /{ }^{235} \mathrm{U}$ isotopic ratio reported in Steiger and Yäger (1977) were used in this study. ${ }^{207} \mathrm{~Pb} /{ }^{235} \mathrm{Uc}\left({ }^{235} \mathrm{Uc}=137.88 \mathrm{x}{ }^{238} \mathrm{U}\right),{ }^{206} \mathrm{~Pb} /{ }^{238} \mathrm{U}$, and ${ }^{207} \mathrm{~Pb} /{ }^{206} \mathrm{~Pb}$ ages were calculated for each data scan and checked for concordance; concordance here was defined as overlap of all three ages at the $1 \sigma$ level (the use of $2 \sigma$ level was found to skew the results to include scans with significant common $\mathrm{Pb}$ ). The background-corrected isotopic sums of each isotope were calculated for all concordant scans. The precision of each isotopic ratio was calculated by using the background and signal errors for both isotopes. The 
fractionation factor for each data scan, corrected for the effect of accumulated $\alpha$-damage, was weighted according to the ${ }^{238} \mathrm{U}$ or ${ }^{232} \mathrm{Th}$ signal value for that data scan; an overall weighted mean fractionation factor for all concordant data scans was used for final age calculation.

If the number of concordant data scans for a spot was greater than zero, then either the ${ }^{206} \mathrm{~Pb} /{ }^{238} \mathrm{U}$ age (for ages less than $1.5 \mathrm{Ga}$ ) or the ${ }^{207} \mathrm{~Pb} /{ }^{206} \mathrm{~Pb}$ age (for ages greater than $1.5 \mathrm{Ga}$ ) was chosen as the preferred age. If zero concordant data scans were observed, then the analysis was deleted. Common $\mathrm{Pb}$ was subtracted out using the Stacey and Kramer (1975) common $\mathrm{Pb}$ model for Earth. Ages and common $\mathrm{Pb}$ ratio were determined iteratively using a pre-set, session-wide minimum common $\mathrm{Pb}$ age value (default for each session was the age of the oldest age standard, which for these analyses was 1,099 Ma FC-1).

Concordia diagrams, ranked date-weighted mean plots, and kernel density estimates (KDEs) were created using the free online version of Isoplot $\mathrm{R}$ (Vermeesch, 2018). KDEs were plotted for dates younger than $500 \mathrm{Ma}$ only, using automatic kernel bandwidth, allowing adaptive $\mathrm{KDE}$, and normalizing the area under the KDEs.

\section{Calculation of Maximum Depositional Ages}

To establish MDAs for our samples we used the youngest statistical population (YSP) approach of Coutts and others (2019). A YSP MDA is the weighted mean of two or more of the youngest zircons that yield a mean square weighted deviation (MSWD) closest to 1.0; these weighted mean dates were calculated using a spreadsheet developed by Boise State University Isotope Geology Laboratory (Herriott and others, 2019). Herriott and others (2019) demonstrated that YSP MDAs of LA-ICP-MS detrital zircon dates closely approximated chemical-abrasion-thermal ionization mass spectrometry (CA-TIMS)-based MDAs, and YSPs have a low probability of producing MDAs that are younger than true depositional ages (Coutts and others, 2019). Uncertainties for the YSP MDAs reported in table 1 include both analytical and systematic sources of uncertainty; these uncertainties were propagated into the total uncertainty by quadrature. We assumed a systematic uncertainty factor following the example of Coutts and others (2020), but we used a more conservative value of 2 percent $\left({ }^{206} \mathrm{~Pb} /{ }^{238} \mathrm{U}\right.$; $2 \sigma$; see Horstwood and others, 2016, and Spencer and others, 2016).

\section{DESCRIPTIONS OF SAMPLES}

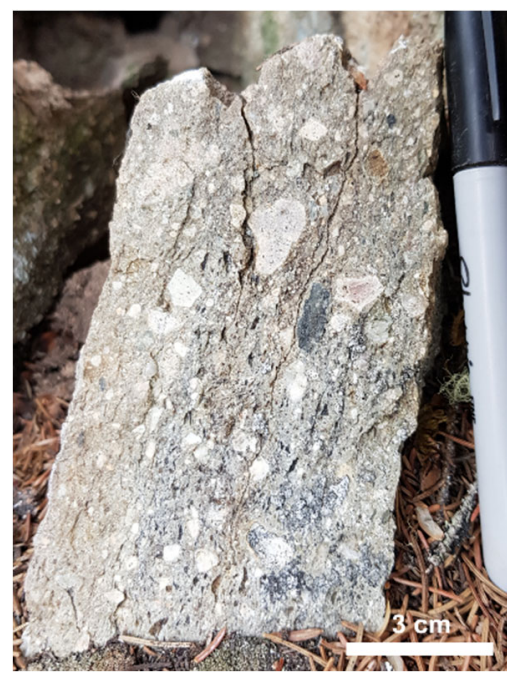

\section{ET330}

Volcaniclastic conglomerate; pale blue-green, massive, flaggy weathering, with subrounded to subangular clasts that are very poorly sorted and range from 0.1 to $25 \mathrm{~mm}$ in diameter (figs. 2 and 3). Clasts are supported by an extremely fine-grained, possibly tuffaceous, matrix that includes aligned, sub-50-micron white mica. Clasts are dominated by mono- and polycrystalline quartz, felsic tuff lithics, detrital feldspar and white mica, and minor felsic porphyry (fig. 3). Sample collected from subcrop.

Figure 2. Outcrop photograph of the source of sample 19ET330. 

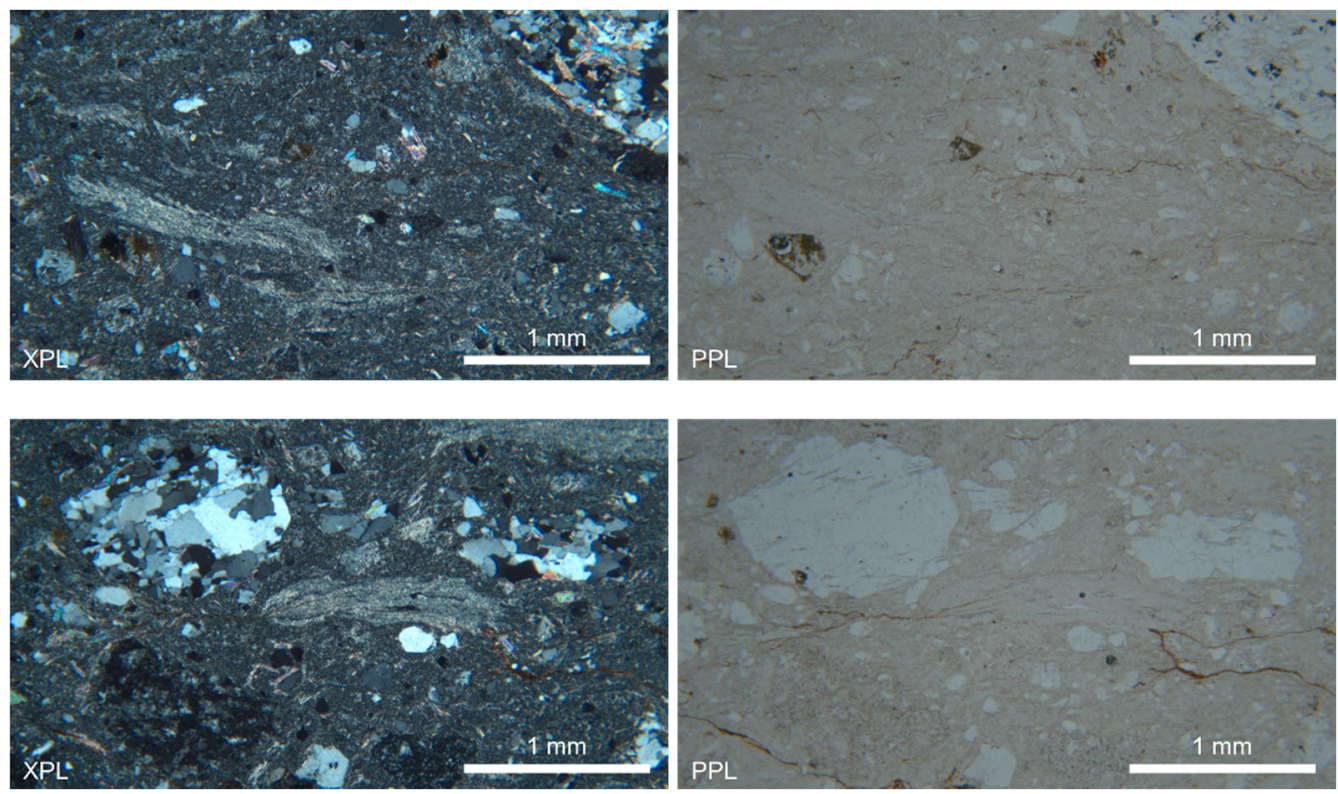

Figure 3. Photomicrographs of sample 19ET330. XPL—cross-polarized light; PPL—plane-polarized light.

\section{AW206}

Conglomerate; pale brown, well-indurated, clast-supported, and very poorly sorted. Grain size ranges from 1 to $100 \mathrm{~mm}$. Clasts are subrounded to angular and are dominated by polycrystalline quartz, with lesser schist, metamafic rocks, and rare felsic porphyry or porphyritic volcanic rock clasts. Detrital feldspar and possible detrital white mica are also present. Some clasts with metamorphic fabric appear to be ductiley deformed during diagenesis (fig. 4). Sample collected from subcrop.
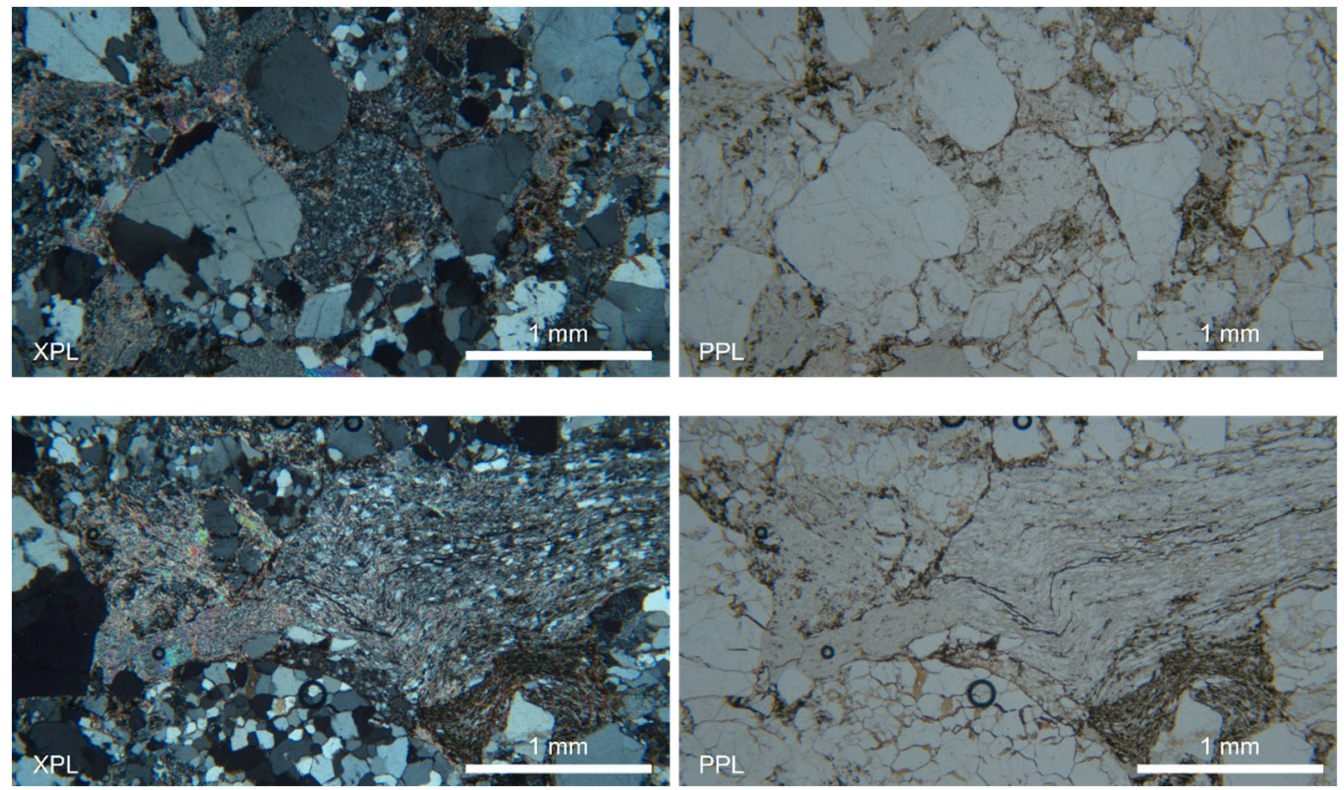

Figure 4. Photomicrographs of sample 19AW206. XPL—cross-polarized light; PPL—plane-polarized light. 
$19 K S 430$

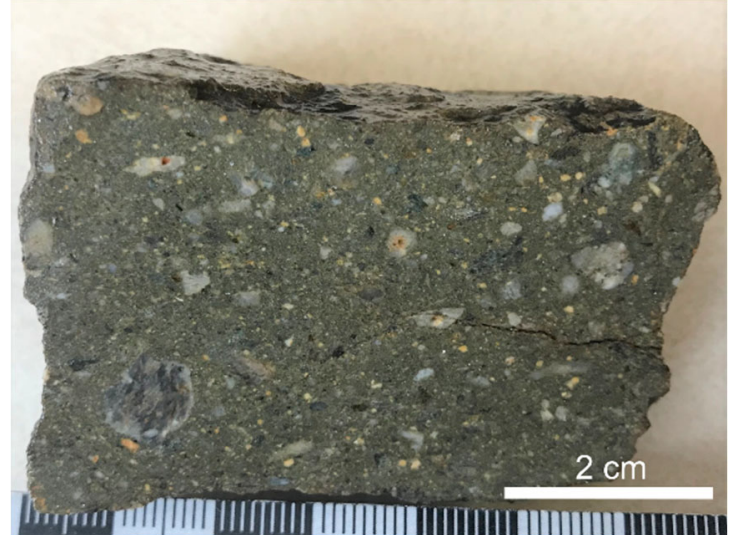

Conglomerate; greenish gray, well-indurated, clast- to matrix-supported, and poorly sorted. Clasts are subrounded to subangular, 0.1 to $5 \mathrm{~mm}$ in diameter; matrix is very finegrained and characterized by a significant fraction of 0.1-0.5 $\mathrm{mm}$, somewhat-aligned diagenetic white mica (figs. 5 and 6). Clasts are dominated by quartz, polycrystalline granoblastic quartz, quartz-feldspar-white mica paragneiss, detrital white mica and feldspar, and minor devitrified felsic volcanic rocks. Sample collected from colluvium.

Figure 5. Hand sample photograph of sample 19KS430.
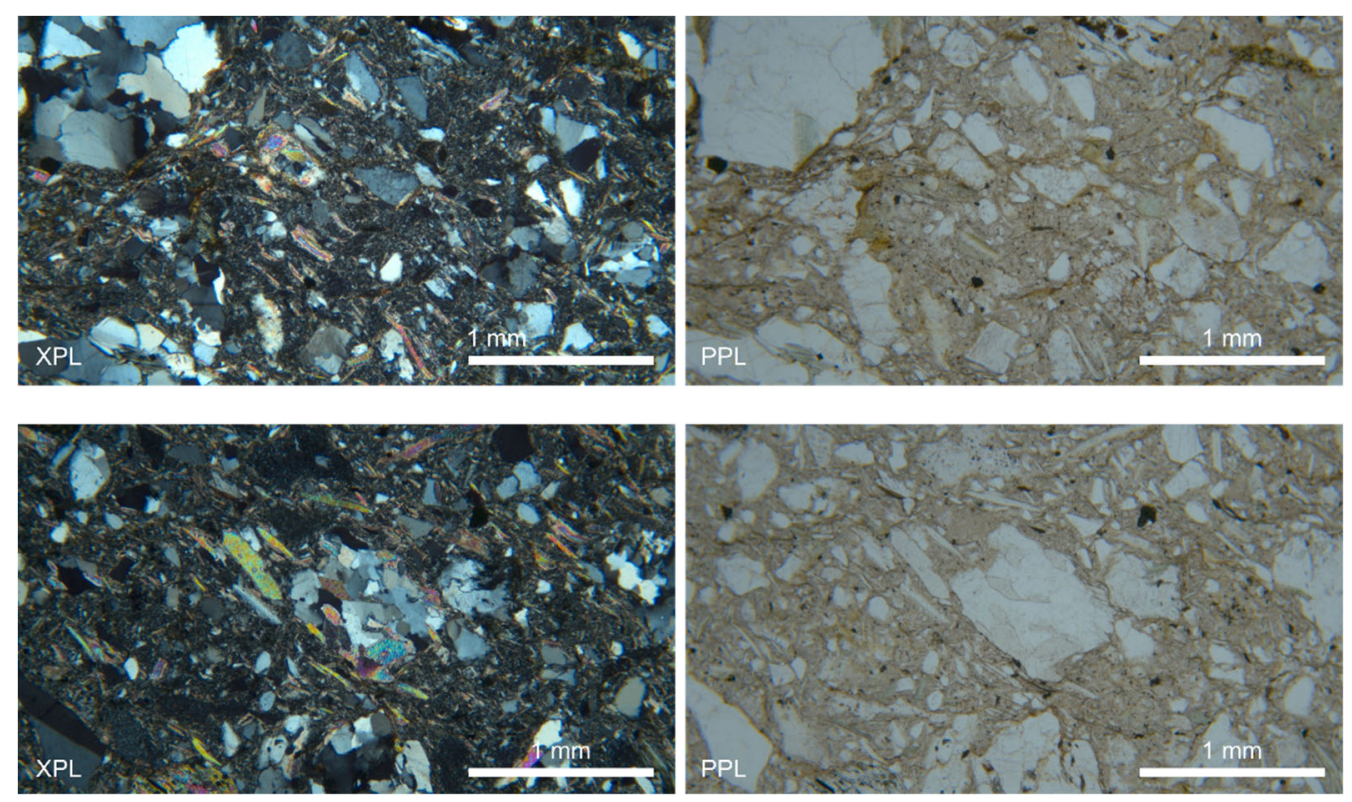

Figure 6. Photomicrographs of sample 19KS430. XPL—cross-polarized light; PPL—plane-polarized light.

\section{RESULTS}

All samples are dominated by multiple populations of concordant Phanerozoic zircons, plus scattered Proterozoic zircons (figs. 7, 8, 9). The YSP maximum depositional age (MDA) for each sample is listed in table 1. Refer to the associated digital data files for complete results. 

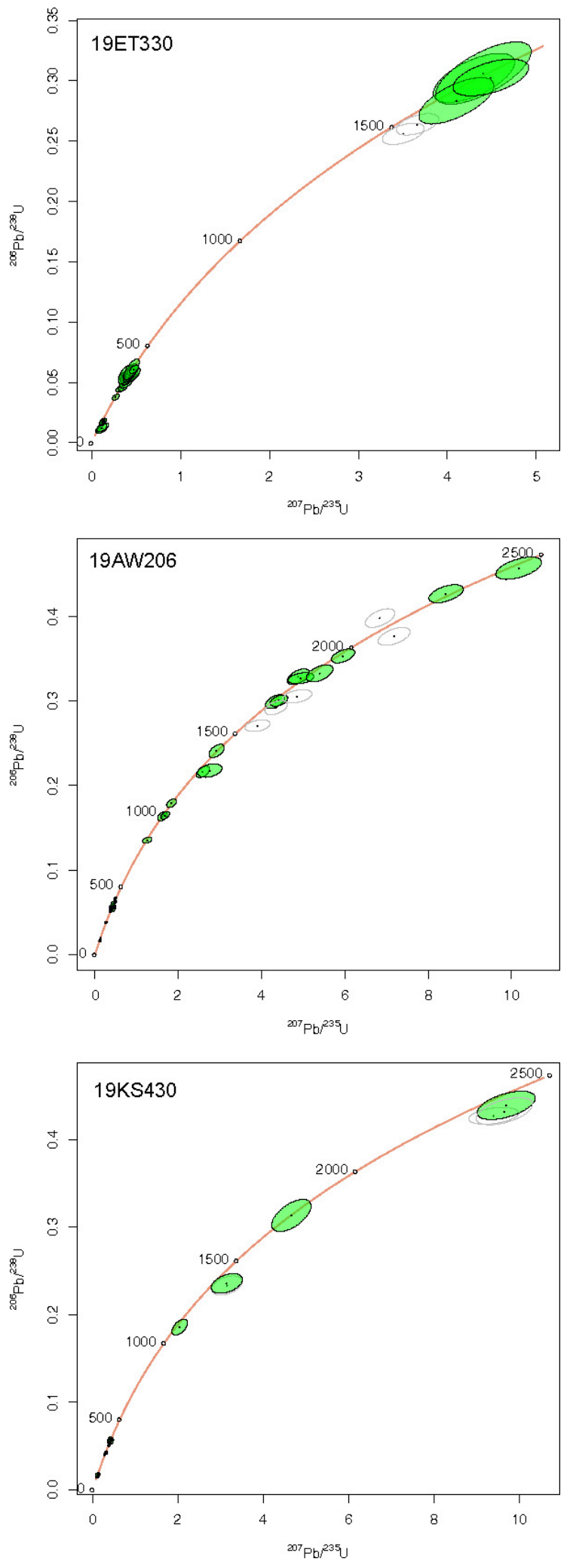

Figure 7. Wetherill concordia diagrams illustrating all zircon analyses presented in this report. Where $2 \sigma$ error ellipses do not overlap the concordia line the ellipse is shown in gray. No Phanerozoic zircons are discordant in these samples. Concordia line units are Ma. 


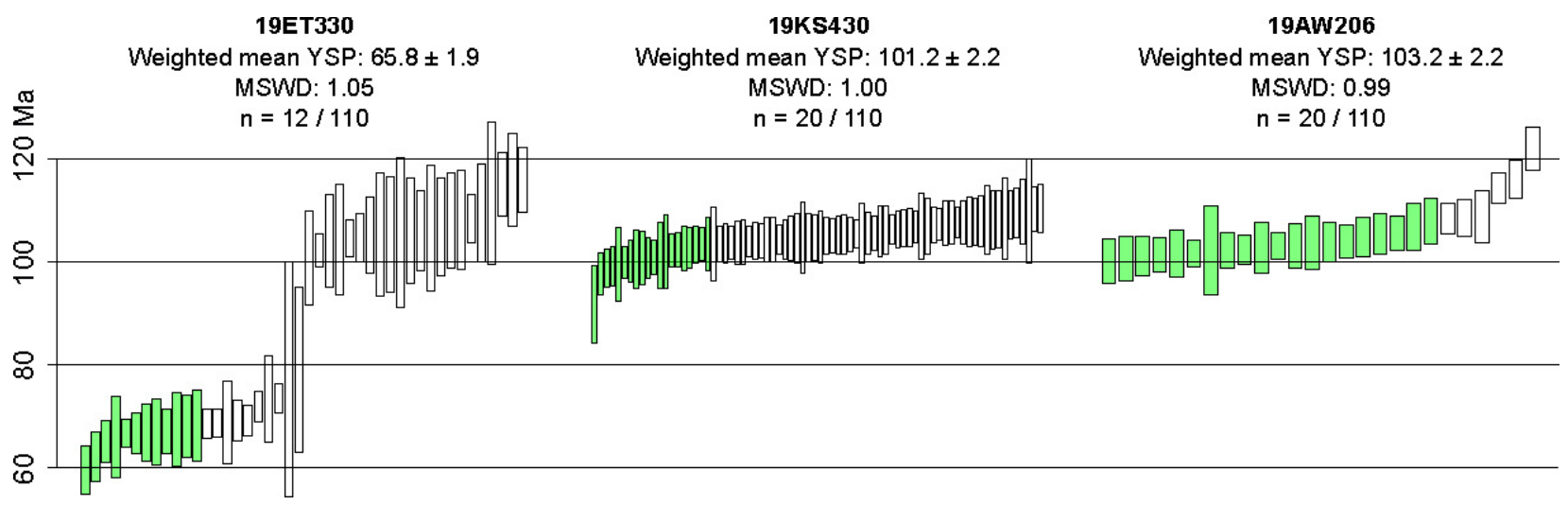

Figure 8. Ranked-date plots illustrating the Cretaceous ages from samples 19ET330, 19AW206, and 19KS430. Boxes represent uncertainty at the $2 \sigma$ level.

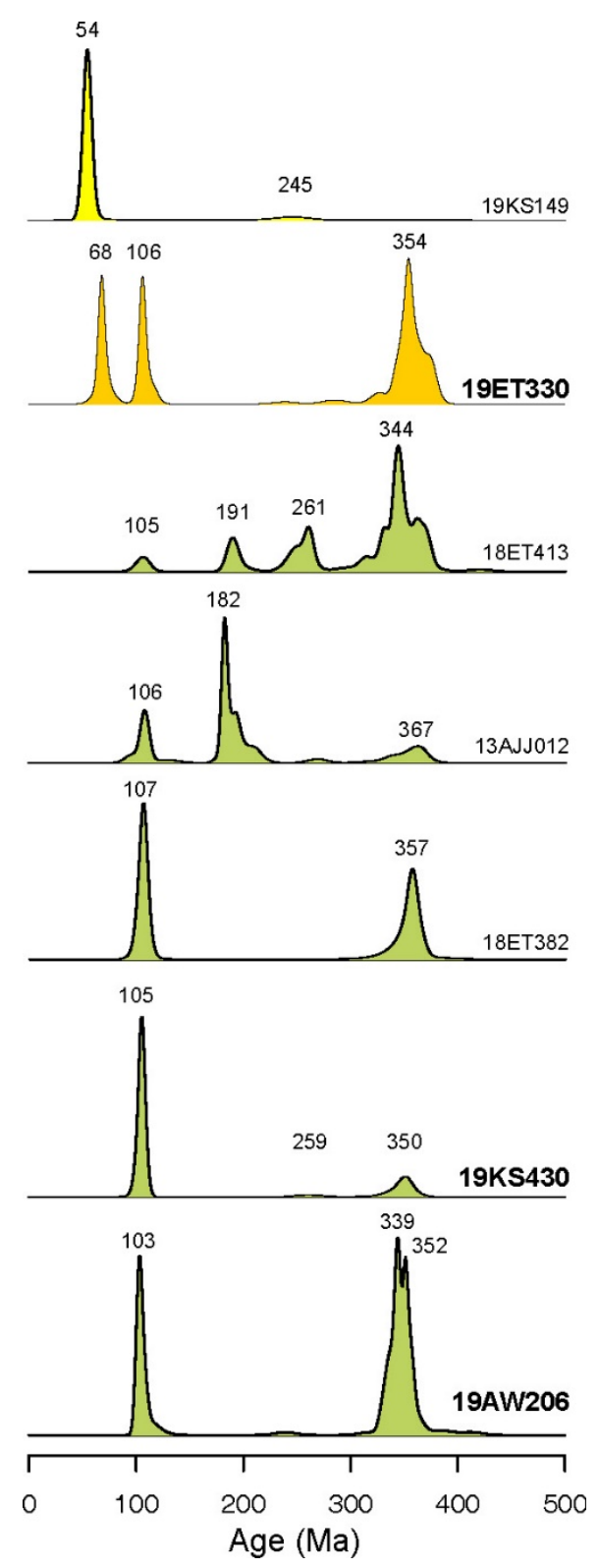

Figure 9. Stacked kernel density estimate (KDE) diagrams comparing the Phanerozoic fraction of the detrital zircon data from this publication (bold sample numbers), with additional nearby samples from other publications for comparative purposes. 18ET382 and 18ET413 are from Wypych and others (2020), and 19KS149 and 13AJJ012 are from Jones and O'Sullivan (2020). Labeled peak ages are picked graphically from the peak population and differ from the YSPs. 
Table 1. Youngest statistical population (YSP) maximum depositional ages (MDAs) for the three detrital zircon samples presented in this report, as well as YSPs for other samples in the region calculated by the same method.

\begin{tabular}{|c|c|c|c|c|c|c|c|}
\hline Sample & $\begin{array}{l}\text { Latitude } \\
\text { (WGS84) }\end{array}$ & $\begin{array}{l}\text { Longitude } \\
\text { (WGS84) }\end{array}$ & Lithology & $\begin{array}{l}\text { YSP (Ma) } \\
\pm 2 \sigma\end{array}$ & MSWD & $\begin{array}{l}\text { n (YSP) / } \\
\text { n sample }\end{array}$ & Ref. \\
\hline 19 ET330 & 63.46422 & -141.74330 & $\begin{array}{l}\text { Volcaniclastic } \\
\text { conglomerate }\end{array}$ & $65.8 \pm 1.9$ & 1.05 & $12 / 110$ & 1 \\
\hline $19 K S 430$ & 63.69819 & -142.20671 & Conglomerate & $101.2 \pm 2.2$ & 1.00 & $20 / 110$ & 1 \\
\hline 19AW206 & 63.38672 & -142.39418 & Conglomerate & $103.2 \pm 2.2$ & 0.99 & $20 / 110$ & 1 \\
\hline 18ET382 & 63.91984 & -141.24540 & Sandstone & $99.4 \pm 2.4$ & 1.56 & $10 / 110$ & 2 \\
\hline $18 \mathrm{ET} 413$ & 63.87954 & -141.64912 & Conglomerate & $104.7 \pm 3.6$ & 1.11 & $4 / 110$ & 2 \\
\hline 13AJJ012 & 64.1691 & -140.5432 & Conglomerate & $95.6 \pm 2.0$ & 1.92 & $3 / 94$ & 3 \\
\hline 19KS149 & 63.39117 & -141.12155 & Conglomerate & $54.0 \pm 1.1$ & 1.00 & $70 / 110$ & 3 \\
\hline 1. & tudy & & & & & & \\
\hline $\begin{array}{l}2 . \\
3 .\end{array}$ & $\begin{array}{l}\text { ch and ot } \\
\text { and O'Su }\end{array}$ & $\begin{array}{l}(2020) \\
\ln (2020)\end{array}$ & & & & & \\
\hline
\end{tabular}

\section{DISCUSSION}

Samples 19KS430 and 19AW206 exhibit similar detrital zircon signatures that are dominated by zircon populations around $\sim 350 \mathrm{Ma}$ and $\sim 105 \mathrm{Ma}$ (fig. 9). The older population reflects Mississippian-Devonian magmatism common to both parautochthonous North America (pNA) and the allochthonous YukonTanana Terrane (YTT), and the $105 \mathrm{Ma}$ population is coeval with the mid-Cretaceous granite and granodiorite batholith intruding pNA to the south and west of the sample sites (see fig. 1; Solie and others, 2014; Wildland and others; 2021). The $\sim 105$ Ma population includes dates that constrain the maximum depositional ages for 19AW206 and 19KS430 (table 1). A minimum age for 19KS430 is constrained by overlying alkaline volcanic rocks, which we infer to be latest Cretaceous based on an apparent correlation to the alkaline Carmacks Group volcanic rocks of Yukon (unit lKav; Twelker and others, 2021).

Sample 19AW206 was sampled from strata that lie directly on metamorphic basement in proximity to modern exposures of the mid-Cretaceous batholith (fig. 10), while sample 19KS430 was collected from conglomerate deposited on top of the West Fork tuff (U-Pb zircon weighted mean age of 107.9 $\pm 2.2 \mathrm{Ma}$, youngest single zircon grain dated at 105.3 $\pm 1.2 \mathrm{Ma}$; Wildland and others, 2021). The YSP of 19KS430, 101.2 $\pm 2.2 \mathrm{Ma}$, is significantly younger than the West Fork tuff, and its zircon populations are seemingly too diverse for the tuff to have been a major sediment source. The lithologic, provenance signature, and MDA similarities suggest that 19AW206 and 19KS430 were deposited by the same Cretaceous depositional system. We infer that metamorphic basement is at least $300 \mathrm{~m}$ lower (the minimum thickness of the West Fork tuff estimated from Twelker and others, 2021) at 19KS430 than it is at 19AW206 (fig. 10). These relations are seemingly consistent with the mid-Cretaceous volcanic caldera proposed by Bacon and others (1990); however, exposure in the area is poor, and there is no direct evidence for caldera-bounding structures (Twelker and others, 2021).

The 19ET330 KDE resembles KDEs for 19KS430 and 19AW206, with the notable addition of an 66 Ma zircon population (figs. 8 and 9). This young population is probably derived from the abundant felsic volcanic material present in this sample and absent from the others. The $65.8 \pm 1.9 \mathrm{Ma}$ YSP MDA may be a 
close approximation of stratal age, as suggested by the volcaniclastic nature of this rock, and its lack of ca. 57 Ma zircons from volcanic and shallow intrusive rocks mapped in the area by Twelker and others (2021). The 19ET330 MDA is also slightly younger than $\mathrm{U}-\mathrm{Pb}$ zircon magmatic ages for intrusive rocks in the Taurus and Pika areas (67.7 - 71.0 Ma; Todd and others, 2019; Wypych and others, 2020) but overlaps the zircon crystallization age of quartz monzonite at Mount Fairplay within error (66.5 \pm 1.1 Ma; Dusel-Bacon and others, 2015).

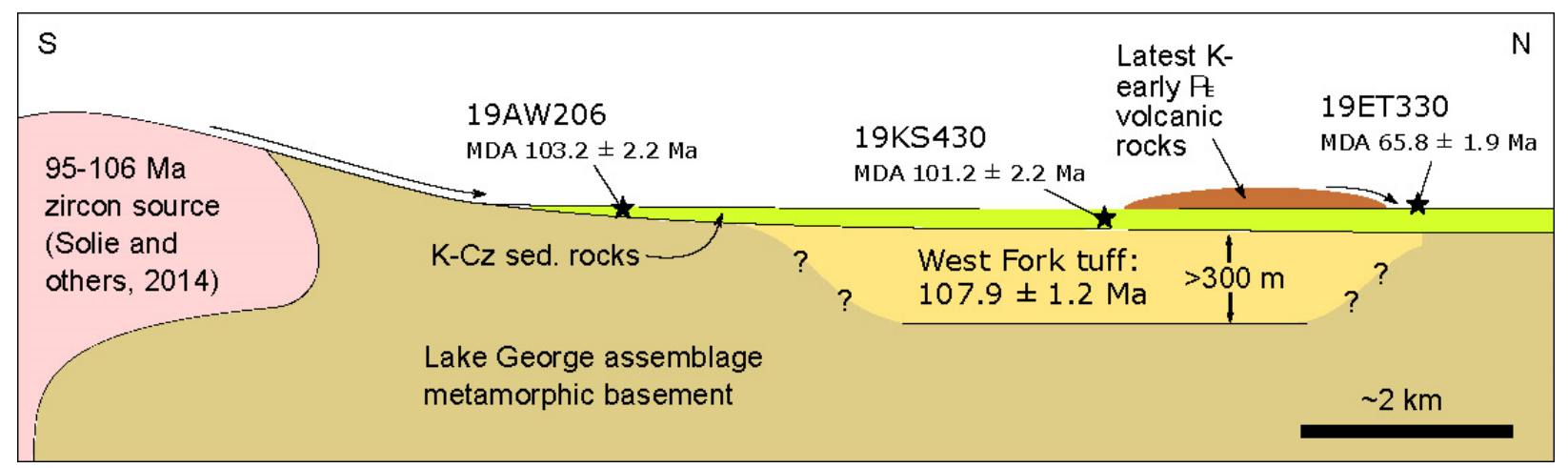

Figure 10. Schematic regional cross section illustrating provenance and stratigraphic relations associated with CretaceousCenozoic strata (green). Detrital zircons in the sampled units are derived from mid-Cretaceous plutons (pink), the Lake George assemblage (brown), and, in the case of 19ET330, latest Cretaceous to early Paleogene volcanic rocks (orange). Vertical scale is greatly exaggerated relative to horizontal scale; both vertical and horizontal scales are approximate.

The provenance of all three samples presented here is apparently dominated by the MississippianDevonian Divide Mountain augen gneiss and the mid-Cretaceous plutons (and coeval volcanic rocks) that intrude the Lake George assemblage in this region. A few Permian zircons could be sourced from volcanic or intrusive rocks within the Klondike assemblage, or Permian intrusive rocks found in the Ladue River area (Jones and O'Sullivan, 2020; Wildland and others, 2021). However, our samples lack the prominent 180-190 Ma zircon population derived from Early Jurassic plutonic rocks that are restricted to the allochthonous Fortymile River assemblage. In this respect, they are different from two similar-age samples taken to the north (18ET413 of Wypych and others [2020]; and 13AJJ012 of Jones and O'Sullivan [2020]; fig. 1), which have Jurassic and Permian zircon populations and much smaller mid-Cretaceous zircon populations (fig. 9). The detrital zircon signatures of these samples are consistent with provenance in the nearby allochthonous YTT and its associated plutonic rocks. However, sample 18ET382 (Wypych and others, 2020) depositionally overlies the Fortymile River assemblage (part of the YTT) but does not contain the diagnostic Jurassic or Permian zircon populations associated with the YTT. Interestingly, 18ET413 and 13AJJ012 contain very few Late Triassic zircons, despite relative proximity to the Taylor Mountain batholith (ca. 212 Ma; Dusel-Bacon and others, 2015). This may be due to paleogeography or to relatively low zircon content of the Triassic intrusions, which are more mafic (mostly quartz diorite to granodiorite; Wilson and others, 2015) than the nearby Jurassic plutons.

The variation in detrital zircon populations between samples, the similarity to local bedrock geology, and the low thickness of the sampled beds suggests that these coarse-clastic strata were deposited in the proximal parts of a terrestrial sedimentary system. Most of the sediment load would have been bypassed to higher- 
accommodation, down-reach parts of the system, such as the thicker, coal-bearing strata described locally in the region by Foster and others (1994). An ultimate sediment sink may resemble the fan-deltas described in the Tantalus basin (Indian River Formation) of Yukon; however, these deposits are southwest-prograding and have provenance to the northeast (Lowey and Hills, 1988). The present-day distribution of Jurassic and Cretaceous plutons near our samples suggests sedimentary source areas either south or west of the sampled deposits (fig. 1).

Yeend (1996) observed that, regionally, the placer gold resources of the Fortymile District (the Alaska extension of the Klondike placer district) closely match the spatial extent of the allochthonous Fortymile River assemblage, a heterogeneous bedrock unit comprising amphibolite, orthogneiss, schist, and marble (for example, Werdon and others, 2001). The major bedrock source of placer gold in the region is orogenic-type gold-bearing quartz veins that formed during the Middle to Late Jurassic (Allan and others, 2013). These veins are broadly distributed but rarely found in concentrations of interest to lode exploration. They are restricted to the allochthonous units of the YTT, as are the Triassic and Jurassic plutonic rocks of the Fortymile areaboth were emplaced prior to the final tectonic assembly of the region. Based on recent detrital zircon results from the area (Wypych and others, 2020, Jones and O'Sullivan, 2020; this study), it appears that some of the Late Cretaceous clastic sedimentary rocks are derived from the allochthonous YTT (the samples with a Jurassic zircon population), while others are derived mainly from pNA and its associated mid-Cretaceous magmatic rocks. Cretaceous depositional systems with sediment sourced from the YTT had the potential to transport and concentrate Jurassic orogenic gold. These sedimentary rocks may have been a source for modern placer deposits, as postulated for Coal and Woodchopper creeks between Circle and Eagle (Cobb, 1973), or they could themselves potentially host paleo-placer gold deposits. However, despite its proximity to Cretaceous-Cenozoic sedimentary deposits, placer gold at Chicken Creek is only slightly rounded and larger nuggets have quartz attached; it is not far-traveled and is unlikely to be recycled through the sedimentary rocks. A prospective lode source, the Purdy lode mine, lies at the head of the drainage (Werdon and others, 2004).

\section{ACKNOWLEDGMENTS}

We thank Trystan M. Herriott for his constructive review and guidance in the fields of sedimentology and of detrital zircon interpretation, Robert J. Gillis for sharing his knowledge of detrital zircon geochronology, and Melanie Werdon for her review and discussion of the regional bedrock geology.

Doyon Limited owns part of the land in the 2019 DGGS study area, including the site of sample 19AW206, and we thank them for permission to work on these lands.

This project was jointly funded by the State of Alaska and the U.S. Geological Survey's Earth Mapping Resources Initiative (Earth MRI) through cooperative agreement G19AC00262. The views and conclusions contained in this document are those of the authors and should not be interpreted as representing the opinions or policies of the U.S. Geological Survey. Mention of trade names or commercial products does not constitute their endorsement by the U.S. Geological Survey. 


\section{REFERENCES}

Allan, M.M., Mortensen, J.K., Hart, C.R, Bailey, L.A., Sanchez, M.G., Ciolkiewicz, Wiltold, McKenzie, G.G., and Creaser, R.A., 2013, Magmatic and metallogenic framework of west-central Yukon and eastern Alaska, in Colpron, Maurice, Bissig, Thomas, Rusk, B.G., and Thompson, J.F.H., Tectonics, Metallogeny, and Discovery: The North American Cordillera and Similar Accretionary Settings, Society of Economic Geologists, Special Publication 17, p. 111-168.

Bacon, C.R., Foster, H.L., and Smith, J.G., 1990, Rhyolitic calderas of the Yukon-Tanana terrane, east-central Alaska; Volcanic remnants of a mid-Cretaceous magmatic arc: Journal of Geophysical Research, v. 95, n. B13, p. 21,451-21,461.

Black, L.P., Kamo, S.L., Allen, C.M., Davis, D.W., Aleinikoff, J.N., Valley, J.W., Mundil, Roland, Campbell, I.H., Korsch, R.J., Williams, I.S., and Foudoulis, Chris, 2004, Improved ${ }^{206} \mathrm{~Pb} /{ }^{238} \mathrm{U}$ microprobe geochronology by the monitoring of trace-element-related matrix effect; SHRIMP, ID-TIMS, ELAICP-MS and oxygen isotope documentation for a series of zircon standards: Chemical Geology, v. 205, n. 1-2, p. 15-140.

Bradley, Dwight, Haeussler, Peter, O'Sullivan, P.B., Friedman, Rich, Till, Alison, Bradley, Dan, and Trop, Jeff, 2009, Detrital zircon geochronology of Cretaceous and Paleogene strata across the south-central Alaskan convergent margin, in Haeussler, P.J., and Galloway, J.P., comps., Studies by the U.S. Geological Survey in Alaska, 2007: U.S. Geological Survey Professional Paper 1760-F, 36 p.

Chang, Zhaoshan, Vervoort, J.D., McClelland, W.C., and Knaack, Charles, 2006, U-Pb dating of zircon by LA-ICP-MS: Geochemistry, Geophysics, Geosystems, American Geophysical Union, v. 7, n. 5, 14 p. Cobb, E.H., 1973, Placer deposits of Alaska: U.S. Geological Survey Bulletin 1374, 213 p., 1 sheet. Coutts, D.S., Matthews, W.A., Englert, R.G., Brooks, M.D., Boivin, Marie-Pier, and Hubbard, S.M., 2020, Along-strike variations in sediment provenance within the Nanaimo basin reveal mechanisms of forearc basin sediment influx events: Lithosphere, v. 12, p. 180-197.

Coutts, D.S., Matthews, W.A., and Hubbard, S.M., 2019, Assessment of widely used methods to derive depositional ages from detrital zircon populations: Geoscience Frontiers, v. 10, n. 4, p. 1,421-1,435. https://doi.org/10.1016/j.gsf.2018.11.002

Donelick, R.A, O’Sullivan, P.B., and Ketcham, R.A., 2005, Apatite fission-track analysis: Reviews in Mineralogy and Geochemistry, Mineralogical Society of America, v. 58, p. 49-94.

Dusel-Bacon, Cynthia, Aleinikoff, J.N., Day, W.C., and Mortensen, J.K., 2015, Mesozoic magmatism and timing of epigenetic $\mathrm{Pb}-\mathrm{Zn}$ - $\mathrm{Ag}$ mineralization in the western Fortymile mining district, east-central Alaska: Zircon U-Pb geochronology, whole-rock geochemistry, and Pb isotopes: Geosphere, v. 11, n. 3. https://doi.org/10.1130/GES01092.1

Foster, H.L., and Igarashi, Yaeko, 1990, Fossil pollen from nonmarine sedimentary rocks of the eastern Yukon-Tanana region, east-central Alaska, in Dover, J.H., and Galloway, J.P., eds., Geologic studies in Alaska by the U.S. Geological Survey, 1989: U.S. Geological Survey Bulletin 1946, p. 11-20.

Foster, H.L., Keith, T.E.C., and Menzie, W.D., 1994, Geology of the Yukon-Tanana area of east-central Alaska: Geological Society of America, p. 205-240. 
Gehrels, G.E., Valencia, V.A., and Ruiz, Joaquin, 2008, Enhanced precision, accuracy, efficiency, and spatial resolution of $\mathrm{U}-\mathrm{Pb}$ ages by laser ablation-multicollector-inductively coupled plasma-mass spectrometry: Geochemistry Geophysics Geosystems, American Geophysical Union, v. 9, 13 p.

Gordey, S.P., and Ryan, J.J., 2005, Geology, Stewart River Area (115 N, 115-O and part of 115-J): Yukon Territory: Geological Survey of Canada Open File 4970, 1 sheet, scale 1:250,000.

Herriott, T.M., Crowley, J.L., Schmitz, M.D., Wartes, M.A., and Gillis, R.J., 2019, Exploring the law of detrital zircon: LA-ICP-MS and CA-TIMS geochronology of Jurassic forearc strata, Cook Inlet, Alaska, USA: Geology, v. 47.

Horstwood, M.S., Košler, Jan, Gehrels, G.E., Jackson, S.E., McLean, N.M., Paton, Chad, Pearson, N.J., Sircombe, Kieth, Sylvester, Paul, Vermeesch, Pieter, and Bowring, J.F., 2016, Community-derived standards for LA-ICP-MS U-(Th-) Pb geochronology-Uncertainty propagation, age interpretation and data reporting: Geostandards and Geoanalytical Research, v. 40, n. 3, p. 311-332.

Hults, C.P., Wilson, F.H., Donelick, R.A., and O'Sullivan, P.B., 2013, Two flysch belts having distinctly different provenance suggest no stratigraphic link between the Wrangellia composite terrane and the paleo-Alaskan margin: Geological Society of America, Lithosphere v. 5, n. 6, p. 575-594.

\section{https://doi.org10.1130/L310.1}

Jones III, J.V., and O'Sullivan, Paul, 2020, U-Pb isotopic data and ages of zircon, titanite, and detrital zircon from rocks from the Yukon-Tanana Upland, Alaska: U.S. Geological Survey data release. https://doi.org/10.5066/P9WWV93S

Lanphere, M.A. and Baadsgaard, H., 2001, Precise K-Ar, ${ }^{40} \mathrm{Ar} /{ }^{39} \mathrm{Ar}, \mathrm{Rb}-\mathrm{Sr}$ and U-Pb mineral ages from the 27.5 Ma Fish Canyon Tuff reference standard: Chemical Geology, v. 175, p. 653-671.

Lowey, G.V., and Hills, L.V., 1988, Lithofacies, petrography and environments of deposition, Tantalus Formation (Lower Cretaceous) Indian River area, West-Central Yukon, Bulletin of Canadian Petroleum Geology, v. 36, p. 296-310.

Moore, T.E., O'Sullivan, P.B., Potter, C.J., and Donelick, R.A., 2015, Provenance and detrital zircon geochronologic evolution of lower Brookian foreland basin deposits of the western Brooks Range, Alaska, and implications for early Brookian tectonism: Geosphere, v. 11, p. 93-122. https://doi.org/10.1130/GES01043.1

Paces, J.B., and Miller, J.D., 1993, Precise U-Pb ages of Duluth Complex and related mafic intrusions, northeastern Minnesota: Geochronological insights to physical, petrogenic, paleomagnetic, and tectonomagmatic processes associated with the $1.1 \mathrm{Ga}$ Midcontinent Rift System: Journal of Geophysical Research, v. 98, p. 13,997-14,013.

Renne, P.R., Swisher, C.C., Deino, A.L., Karner, D.B., Owens, T.L., and DePaolo, D.J., 1998, Intercalibration of standards, absolute ages and uncertainties in ${ }^{40} \mathrm{Ar} /{ }^{39} \mathrm{Ar}$ dating. Chemical Geology, v. 45, p. 117-152.

Solie, D.N., O'Sullivan, P.B., Werdon, M.B., Freeman, L.K., Newberry, R.J., Szumigala, D.J., and Hubbard, T.D., 2014, Zircon U-Pb age data, Alaska Highway corridor, Tanacross and Nabesna quadrangles, Alaska: Alaska Division of Geological \& Geophysical Surveys Raw Data File 2014-16, 29 p. https://doi.org/10.14509/27322

Spencer, C.J., Kirkland, C.L., and Taylor, R.J., 2016, Strategies towards statistically robust interpretations of in situ U-Pb zircon geochronology: Geoscience Frontiers, v. 7, n. 4, p. 581-589. 
Stacey, J.S., and Kramer J.D., 1975, Approximation of terrestrial lead isotope evolution by a two-stage model: Earth and Planetary Science Letters, v. 26, p. 207-221.

Steiger, R.H., and Jäger, Emilie, 1977. Subcommission on geochronology: Convention on the use of decay constants in geo- and cosmochronology. Earth and Planetary Science Letters, v. 36, p. 369-371.

Todd, Erin, Wypych, Alicja, and Kylander-Clark, Andrew, 2019, U-Pb and Lu-Hf isotope, age, and trace element data from zircon separates from the Tanacross D-1, and parts of D-2, C-1, and C-2 quadrangles: Alaska Division of Geological \& Geophysical Surveys Raw Data File 2019-5, 10 p. https://doi.org/10.14509/30198

Twelker, Evan, Newberry, R.J., Wypych, Alicja, Naibert, T.J., Wildland, A.D., Sicard, K.R., Regan, S.P., Athey, J.E., Wyatt, W.C., and Lopez, J.A., 2021, Chapter A: Bedrock geologic map of the Ladue RiverMount Fairplay area, Tanacross and Nabesna quadrangles, Alaska, in Twelker, Evan, ed., Geologic investigation of the Ladue River-Mount Fairplay area, eastern Alaska: Alaska Division of Geological \& Geophysical Surveys Report of Investigation 2021-5A. https://doi.org/10.14509/30735

Vermeesch, Pieter, 2018, IsoplotR: a free and open toolbox for geochronology: Geoscience Frontiers, v.9, p. 1,479-1,493. https://doi.org/10.1016/j.gsf.2018.04.001

Werdon, M.B., Flynn, R.L., and Szumigala, D.J., 2004, Alaska Resource Data File, Eagle Quadrangle, Alaska: U.S. Geological Survey Open-File Report 2004-1056, 418 p.

Werdon, M.B., Newberry, R.J., and Szumigala, D.J., 2001, Bedrock geologic map of the Eagle A-2 Quadrangle, Fortymile mining district, Alaska: Alaska Division of Geological \& Geophysical Surveys Preliminary Interpretive Report 2001-3B, 1 sheet, scale 1:63,360. https://doi.org/10.14509/2670

Wildland, A.D., Wypych, Alicja, Regan, S.P., and Holland, Mark, 2021, U-Pb zircon ages from bedrock samples collected in the Tanacross and Nabesna quadrangles, eastern Alaska: Alaska Division of Geological \& Geophysical Surveys Preliminary Interpretive Report 2021-4, 47 p. https://doi.org/10.14509/30732

Wilson, F.H., Hults, C.P., Mull, C.G., and Karl, S.M., 2015, Geologic map of Alaska: U.S. Geological Survey Scientific Investigations Map 3340, 196 p., 2 sheets, scale 1:1,584,000.

https:/alaska.usgs.gov/science/geology/state map/interactive map/AKgeologic map.html.

Wypych, Alicja, Hubbard, T.D., Naibert, T.J., Athey, J.E., Newberry, R.J., Sicard, K.R., Twelker, Evan, Werdon, M.B., Willingham, A.L., Wyatt, W.C., and Lockett, A.C., 2021, Chapter B: Northeast Tanacross geologic map and map units and descriptions, in Wypych, Alicja, Northeast Tanacross geologic mapping project, Alaska: Alaska Division of Geological \& Geophysical Surveys Report of Investigation 2020-9B. https://doi.org/10.14509/30539

Wypych, Alicja, Jones, J.V., III, and O'Sullivan, Paul, 2020, U-Pb Zircon ages from bedrock samples collected in the Tanacross D-1, and parts of the D-2, C-1, and C-2 quadrangles, Alaska: Alaska Division of Geological \& Geophysical Surveys Preliminary Interpretive Report 2020-2, 19 p. https://doi.org/10.14509/30465

Yeend, W.E., 1996, Gold placers of the historical Fortymile River region, Alaska: U.S. Geological Survey Bulletin 2125, 75 p., 1 sheet, scale 1:63,360.

Yukon Geological Survey, 2019, Yukon Digital Bedrock Geology [website]: www.geology.gov.yk.ca/update yukon bedrock geology map.html [accessed: 3/19/2019] 